Original Article

\title{
ANTIDIABETIC POTENTIAL OF THE OYSTER MUSHROOM PLEUROTUS FLORIDA (MONT.) SINGER
}

\author{
PRABU M.*, KUMUTHAKALAVALLI R. \\ Department of Biology, Gandhigram Rural Institute-Deemed University, Gandhigram 624302 Dindigul (TN), India \\ Email: sma.subi@gmail.com
}

Received: 27 Jan 2017, Revised and Accepted: 20 Apr 2017

\begin{abstract}
Objective: The present investigation comprises, in vitro antidiabetic activity such as $\alpha$-amylase and $\alpha$-glucosidase inhibitory activities and in vivo antidiabetic activity of methanolic extract of Pleurotus florida.

Methods: The fruiting bodies of Pleurotus florida were obtained from Mushroom Unit, Department of Biology, Gandhigram Rural Institute-Deemed University, Gandhigram, Dindigul, Tamil Nadu, India. Sample preparation, qualitative phytochemical analysis, in vitro antidiabetic activities namely $\alpha$-amylase and $\alpha$-glucosidase inhibitory activity and in vivo antidiabetic activity namely evaluation of alloxan induced diabetic rats were carried out following the methods reported previously.
\end{abstract}

Results: In vitro and in vivo antidiabetic activity of $P$. florida exhibited significant results for its $\alpha$-amylase $(94.93 \pm 1.75 \%$ at $1000 \mu \mathrm{g} / \mathrm{ml})$ and $\alpha$ glucosidase inhibitory activity $(84.90 \pm 0.42 \%$ at $1000 \mu \mathrm{g} / \mathrm{ml})$ in a dose-dependent manner. The extract also showed significant antidiabetic activity on in vivo $(\mathrm{p}<0.05)$ at the tested dose level $(200 \mathrm{mg} / \mathrm{kg} \mathrm{b}$. w) this was comparable to Glibenclamide, a standard antidiabetic drug.

Conclusion: The presence of phytochemicals namely phenols, flavonoids, saponins, tannins and terpenoids may be responsible for such antidiabetic activity. These results reveal that $P$. florida can be used as a potential antidiabetic agent.

Keywords: Pleurotus florida, Phenols, Flavonoids, Antidiabetic activity, Antidiabetic agent

(c) 2017 The Authors. Published by Innovare Academic Sciences Pvt Ltd. This is an open access article under the CC BY license (http://creativecommons.org/licenses/by/4.0/) DOI: http://dx.doi.org/10.22159/ijcpr.2017v9i4.20765

\section{INTRODUCTION}

Diabetes mellitus is a metabolic disorder due to absolute or relative insulin deficiency [1]. According to World Health Organization [2] bout $10 \%$ of the total population and about one out of five persons above the age of 50 suffer from this disease and it is a major cause of morbidity and mortality. The increasing worldwide incidence of diabetes mellitus in adults constitutes a global public health burden. It is predicted to be doubled by the year 2030 to about 380 million where in India, China, and the United States will have the largest number of people with diabetes [2]. Diabetes mellitus may present with characteristic symptoms such as thrust, polyuria, blurring of vision and weight loss [3]. The long-term effects of diabetes mellitus include progressive development of the specific complications of retinopathy with blindness, nephropathy that may be lead to renal failure or neuropathy with risk of foot ulcers, amputation, Charcot joints and sexual dysfunction [4]. Currently, available therapy for diabetes includes insulin and various oral antidiabetic agents such as sulfonylurea, biguanide, metformin, $\alpha$-glucosidase inhibitors, troglitazone but these are known to have a number of serious adverse effects in patients [5-7].

Plants and fungi are the main sources of natural compounds used for medicine. They have attracted considerable interest because of their wide variety of bioactive metabolites [8]. The mushrooms are being developed as nutriceutical and nutraceutical to garner the essence of mushrooms and to make consumption easy. Further, scientific validation of traditional knowledge bears evidence of the many positive effects of consuming mushrooms fresh or processed on human health. A wide variety of bioactive compounds isolated from many species of mushrooms have been identified [9].

Pleurotus florida, commonly known as the white oyster mushroom is one of the most economically important edible mushrooms that grow predominantly in tropical regions and it is considered as the valuable health food with high content of protein [10]. Moreover, this mushroom has been demonstrated to possess various valuable biological properties including antioxidant [11], antimicrobial
[12], anti-inflammatory [13], antitumor [14] as well as antidiabetic activities [15-17]. Till now most studies have been focused on in vitro antidiabetic activities of $P$. florida concerning $\alpha$-amylase and $\alpha$-glucosidase activities. Although a wide range of model systems are available for evaluation of antidiabetic activities, the choice mainly depends on the nature of the substances under investigation. There is evidence for discrepancies in antidiabetic activities of substances when tested in vitro and in vivo. Therefore, in the present study, the methanolic extract of $P$. florida was subjected to the qualitative analysis of phytochemicals and also for its antidiabetic activities using in vitro studies namely, $\alpha$-amylase, $\alpha$-glucosidase, and in vivo antidiabetic activity of alloxan induced diabetic rats were carried. The investigation of the local species may yield mycochemicals with novel medicinal properties that can be used for the development of therapeutic agents in diabetes and for other ailments.

\section{MATERIALS AND METHODS}

The fruiting bodies of Pleurotus florida were obtained from Mushroom Unit, Department of Biology, Gandhigram Rural InstituteDeemed University, Gandhigram, Dindigul, Tamil Nadu, India. Sample preparation [18], qualitative phytochemical analysis [19], in vitro antidiabetic activities namely $\alpha$-amylase [20] and $\alpha$-glucosidase [20] inhibitory activity and in vivo antidiabetic activity namely evaluation of alloxan induced diabetic rats were carried out following the methods reported previously [21].

\section{Animal studies}

Animal experiments were carried out according to the guidelines of the Committee for the purpose of control of experiments on animals and approved by the Institutional Animal Ethics Committee (Reg. No.: CPCSEA/265).

\section{Statistical analysis}

The results were expressed as mean values and standard deviation (SD). Linear regression analysis was used to calculate $\mathrm{IC}_{50}$ value. 
Data were analyzed using One-Way Analysis of Variance (ANOVA) followed by Turkey's multiple comparison post hoc tests using SPSS software 16.0 versions.

Values of $p<0.05$ were considered as statistically significant.

\section{RESULTS}

\section{Qualitative phytochemical screening}

Methanolic extract of $P$. florida was qualitatively analyzed and presented in table 1 . Among the various phytochemicals assessed, the presence of phenols, flavonoids, saponins, tannins and terpenoids were detected.

\section{In vitro antidiabetic activity}

The methanolic extract of $P$. florida showed significant inhibition of $\alpha$ amylase $(94.93 \pm 1.75 \%$ at $1.0 \mathrm{mg} / \mathrm{ml})$ and $\alpha$-glucosidase $(84.90 \pm 0.42 \%$ at $1.0 \mathrm{mg} / \mathrm{ml}$ ) inhibitory activity in a dose-dependent manner and the concentrations required for $50 \%$ of the above inhibition $\left(\mathrm{IC}_{50}\right)$ were $35.96 \pm 0.35 \mu \mathrm{g} / \mathrm{ml}$ and $202.02 \pm 3.84 \mu \mathrm{g} / \mathrm{ml}$, respectively (table 2).

\section{In vivo antidiabetic activity}

In vivo antidiabetic study revealed the significant reduction of blood glucose, serum cholesterol, serum triglyceride, LDL levels and significant increase of HDL level in P. florida treated diabetic rats in 14 d's trials (table 3).

Table 1: Qualitative phytochemical screening of Pleurotus florida

\begin{tabular}{lll}
\hline S. No. & Test for extracts & Inference \\
\hline 1. & Phenols & Present \\
2. & Flavonoids & Present \\
3. & Saponins & Present \\
4. & Tannins & Present \\
5. & Terpenoids & Present \\
\hline
\end{tabular}

Table 2: It shows in vitro antidiabetic activities of Pleurotus florida inhibition of $\alpha$-amylase and $\alpha$-glucosidase inhibitory activity

\begin{tabular}{|c|c|c|c|c|}
\hline $\begin{array}{l}\text { Sample concentration } \\
(\mu \mathrm{g} / \mathrm{ml})\end{array}$ & $\alpha$-amylase inhibition activity (\%) & $\begin{array}{l}\text { IC } 50 \text { value } \\
(\mu \mathrm{g} / \mathrm{ml})\end{array}$ & $\alpha$-glucosidase inhibition activity (\%) & $\begin{array}{l}\text { IC }{ }_{50} \text { value } \\
(\mu \mathrm{g} / \mathrm{ml})\end{array}$ \\
\hline 200 & $33.88 \pm 3.18$ & & $28.93 \pm 1.11$ & \\
\hline 400 & $53.80 \pm 4.98$ & & $38.53 \pm 1.79$ & \\
\hline 600 & $64.13 \pm 0.54$ & $35.96 \pm 0.35 \mu \mathrm{g} / \mathrm{ml}$ & $50.40 \pm 0.32$ & $202.02 \pm 3.84 \mu \mathrm{g} / \mathrm{ml}$ \\
\hline 800 & $82.07 \pm 3.03$ & & $78.80 \pm 0.09$ & \\
\hline 1000 & $94.93 \pm 1.75$ & & $84.90 \pm 0.42$ & \\
\hline
\end{tabular}

Data represent the mean $\pm \operatorname{SEM}(n=3)(p<0.05)$

Table 3: It shows in vivo antidiabetic study blood glucose, serum cholesterol, serum triglyceride, LDL and HDL levels of Pleurotus florida treated diabetic rats in $14 \mathrm{~d}$ trials

\begin{tabular}{lllll}
\hline Experimental groups & $\begin{array}{l}\text { Blood glucose } \\
\text { (mg/d) }\end{array}$ & $\begin{array}{l}\text { Serum cholesterol } \\
\text { (mg/dl) }\end{array}$ & $\begin{array}{l}\text { Serum triglyceride } \\
\text { (mg/dl) }\end{array}$ & $\begin{array}{l}\text { LDL } \\
\text { (mg/dl) }\end{array}$ \\
\hline Group-I & $81.40 \pm 3.22^{* *}$ & $34.00 \pm 1.74^{* *}$ & $33.40 \pm 3.45^{* *}$ & $22.00 \pm 2.10^{* *}$ \\
Group-II & $512.00 \pm 15.29$ & $84.0 \pm 4.94$ & $123.00 \pm 6.63$ & $24.60 \pm 1.47^{* *}$ \\
Group-III & $298.20 \pm 12.20^{* *}$ & $72.60 \pm 3.43^{* *}$ & $94.60 \pm 4.81^{*}$ & $58.80 \pm 3.22$ \\
Group-IV & $124.40 \pm 7.84^{* *}$ & $32.20 \pm 2.49^{* *}$ & $38.20 \pm 1.90^{* *}$ & $34.20 \pm 1.61^{* *}$ \\
\hline
\end{tabular}

\section{DISCUSSION}

Pleurotus florida is a good source of extractable phytochemicals with inhibitory potentials against key enzymes namely, $\alpha$-amylase and $\alpha$ glucosidase linked to Type 2 diabetes mellitus. In vitro tests can play a very important role in the evaluation of antidiabetic activity of drugs as initial screening tools, where the screening of a large number of potential therapeutic candidates may be necessary. They might provide useful information on the mechanism of action of therapeutic agents [22-24]. The therapeutic approach for treating Type 2 diabetes is to decrease the post-prandial glucose levels. This could be done by retarding the absorption of glucose through the inhibition of the carbohydrates hydrolyzing enzymes, $\alpha$-amylase and $\alpha$-glucosidase, present in the small intestinal brush border that is responsible for the breakdown of oligosaccharides; disaccharides into monosaccharides suitable for absorption [25-28]. Inhibitors of these enzymes, like acarbose, delay carbohydrate digestion and prolong overall carbohydrate digestion time, causing a reduction in the rate of glucose absorption and consequently blunting the postprandial plasma glucose rise [22]. Jumepaeng et al. [29] reported that the $\alpha$ amylase inhibitory activity was significantly higher as compared to acarbose drug currently administrated for controlling glucose levels in diabetic patients. Natural products from plants have shown lower inhibitory activity against the $\alpha$-amylase activity and stronger inhibitory activity against noninsulin dependent diabetes mellitus
(NIDDM) with minimal side effects. This is a positive result since as explained earlier, the excessive inhibition of $\alpha$-amylase results in the abnormal bacterial fermentation of undigested carbohydrates in the colon, which in turn results in abdominal digestion, flatulence, meteorism and possibly diarrhoea [30].

Alpha-amylase inhibitors are copious in fungi, higher plants, and animals [31]. These living beings create a large number of diverse protein inhibitors of $\alpha$-amylases in order to regulate the activity of these enzymes. Like amylase inhibitors which are also well-known as starch blockers as they avoid dietary starches from being digested and absorbed by the body. This could be helpful for treating obesity and diabetes mellitus [32]. The presence of inhibition to $\alpha$-glucosidase activity in the extracts of $P$. florida could be caused by the presence of carbohydrate and protein (flavanols) which are suspected to be the competitive inhibitors for the $\alpha$-glucosidase enzyme. This is appropriate with the substrate of $\alpha$-glucosidase, which is a food starch and carbohydrate (glycogen) [33]. Alpha-glucosidase inhibitors focusing on reducing the digestion of carbohydrate are the most common and efficacious agents utilized for the treatment of Type 2 diabetes $[34,35]$. Since $\alpha$-glucosidase inhibitors prevent the hybridization of carbohydrates into glucose, a lot of carbohydrates remain in the intestine. Therefore the bacteria will digest carbohydrates, which may cause gastrointestinal side effects such as flatulence and diarrhoea [36]. 
In the present study, in vitro antidiabetic studies revealed the inhibition of $\alpha$-amylase and $\alpha$-glucosidase activity. The percentage inhibition at 200,400,600,800 and $1000 \mu \mathrm{g} / \mathrm{ml}$ concentrations of $P$. florida on $\alpha$-amylase and $\alpha$-glucosidase showed a concentration dependent reduction in percentage inhibition. Therefore, the antidiabetic effect of $P$. florida might attribute to its inhibitory effect against $\alpha$-amylase and $\alpha$-glucosidase that delaying the digestion of carbohydrate to delay the postprandial rise in blood glucose. In the in vivo studies, blood glucose levels were assessed from 0 and $14^{\text {th }}$ days in normal rats; diabetic-induced rats; mushroom extracts treated rats and also glibenclamide-treated rats. There is a significant reduction in all antidiabetic parameters on the $14^{\text {th }}$ day in the rats treated with $P$. florida extracts. In the in vivo studies, alloxan-induced diabetic rats showed the significant increase in the levels of blood glucose than the diabetic rats $(p<0.05)$. Blood glucose level was measured in normal and diabetic rats on day 0 and $14^{\text {th }}$ day of drug treatment. After treatment with both species at 200 $\mathrm{mg} / \mathrm{kg} \mathrm{b.} \mathrm{w}$, the blood glucose levels on day $14^{\text {th }}$ were significantly reduced compared to those on day $0(p<0.01)$. The glibenclamidetreated rats also showed the significant reduction in serum glucose level $(p<0.05)$. P. florida and glibenclamide administration attenuated hyperglycemia, while no significant changes were observed in normal and diabetic groups $(p>0.05)$.

Mushrooms have been shown to be useful in supporting healthy cholesterol levels and have been shown to improve circulation; also they have been shown to help in maintaining blood sugar balance via blood sugar lowering effects, elevation of plasma insulin levels and enhanced liver metabolism of glucose and increase cellular insulin sensitivity [37]. Hyperglycemia caused by diabetes is known to be a cause of oxidative stress that leads mainly to the enhanced production of mitochondrial ROS. Oxidative stress induced by hyperglycemia leads to the activation of stress-sensitive signaling pathways, which worsen both insulin secretion; action and promote the development of Type 2 diabetic mellitus [38-41]. Fasting hyperglycemia is a hallmark of diabetic mellitus. It has been postulated but is still debated that the fasting hyperglycemia in noninsulin-dependent diabetic mellitus arises from the hepatic overproduction of glucose [42].

Wi et al. [43] suggested that the post-absorptive hyperglycemia in Streptozotocin-diabetic rats is largely due to decreasing peripheral glucose clearance, while increased hepatic glucose output might also be a contributing factor at a very high Streptozotocin dose. Krishna et al. [44] stated that polysaccharide extracted from $P$. citrinopileatus showed blood glucose lowering effect in rats. These findings suggest that mushrooms are promising antidiabetic nutriceuticals, but there is the lack of enough clinical evidence. Khan et al. [45] have reported that oral administration of $P$. ostreatus given to rat's leads to blood glucose lowering effect in both insulin-dependent and insulinindependent diabetic conditions. Prabu and Kumuthakalavalli [46] experimentally found that methanolic extract of $C$. indica exhibited antidiabetic activity by lowering the levels of blood glucose, serum cholesterol, serum triglyceride, LDL levels and significant increase of HDL level. Antidiabetic effects of ethanolic extract of $P$. ostreatus on alloxan induced diabetic rats was extensively studied and reported as an effective antidiabetic regimen [47].

\section{CONCLUSION}

The methanolic extract of $P$. florida with its significant antidiabetic activity in rats, suggests its therapeutic potential for the prevention and control of diabetics; moreover, the mushroom species can be used as an easily accessible source of natural antidiabetic and as a possible food supplement or in the pharmaceutical industry. However, more intensive and extensive investigations are needed to exploit their valuable therapeutic potentials and the chemical characteristics of the antidiabetic components in the extracts should be further investigated.

\section{ACKNOWLEDGEMENT}

The authors express their sincere thanks to the Principal, and the Head, Department of Pharmacology, The Periyar College of Pharmaceutical Sciences, Tiruchirapalli, for providing laboratory facilities.

\section{CONFLICT OF INTERESTS}

Declare none

\section{REFERENCES}

1. Zimmet P, Alberti G, Shaw J. Global and societal implications of the diabetes epidemic. Nature 2001;414:782-7.

2. World Health Organization. Traditional Medicinal Strategy 2002-2005. WHO Publications; 2002. p. 1-6.

3. Li WL, Zheng HC, Bukuru J, Kimpe ND. Natural medicines used in the traditional Chinese medical system for therapy of diabetes mellitus. J Ethnopharmacol 2004;92:1-21.

4. Intekhab A, Barry G. Diabetes mellitus. Clin Dermatol 2006;24:237-46.

5. Berger $W$. The incidence of severe side effects during therapy with sulphonylureas and biguanide. Hormones Metabol Res 1985;17:111-5.

6. Rang HP, Dale MM, Ritter JM. The endocrine system pharmacology. Longman Group Ltd. (UK); 1991.

7. Rao BK, Kesavulu MM, Apparao C. Evaluation of the antidiabetic effect of Momordica cynobalaria fruit in alloxan diabetic rats. J Fitoterapia 2003;74:7-13.

8. Cragg GM, Newmann DJ, Snader KM. Natural products in drug discovery and development. J Nat Prod 1997;60:52-60.

9. Wong SP, Naidu M, David P, Bakar R, Vikineswary S. Neurogenerative potential of lions mane mushroom, Hericium erinaceus (Bull.: Fr.) Pers., (Higher Basidiomycetes), in the treatment of peripheral nerve injury. Int J Med Mushrooms 2012;14:427-46.

10. Prakasam V. Current scenario of mushroom research in India. Indian Phytopath 2012;65:1-11.

11. Prabu M, Kumuthakalavalli R. Antioxidant activity of oyster mushroom (Pleurotus florida [Mont.] Singer) and milky mushroom (Calocybe indica $\mathrm{P}$ and $\mathrm{C}$ ). Int J Curr Pharm Res 2016;8:48-51.

12. Ngai PH, Ng TB. A Hemolysin from the mushroom Pleurotus eryngii. Appl Microbiol Biotechnol 2006;75:1185-91.

13. $\mathrm{Hu} \mathrm{SH}$, Chia VC, Lien JL, Chen KS, Lee MY, Wang JC. Antihyperlipidaemic and antioxidant effects of extracts of Pleurotus citrinopileatus. J Agric Food Chem 2006;54:2103-10.

14. Zhang M, Cui SW, Cheung PCK, Wang Q. Antitumor polysaccharides from mushrooms: a review of their isolation process, structural characteristics, and antitumor activity. Trends Food Sci Technol 2007;18:4-19.

15. DeFronzo R, Ferrannini E, Alberti G, Zimmet P. International Textbook of Diabetes Mellitus. $4^{\text {th }}$ ed. Wiley-Blackwell Publishers, Chichester, UK; 2015.

16. Packer L, Rfsen P, Tritschler HJ, King GL, Azzi A. Antioxidants in Diabetes Management. Marcel Dekker, New York; 2000.

17. Silva D, Rapior S, Hyde KD, Bahkali AH. Medicinal mushrooms in prevention and control of diabetes mellitus. Fungal Divers 2012;56:1-29.

18. Suffness M, Douros J. Drugs of plant origin. In: Methods in Cancer Research, Academic Press; New York. DeVita VT, Busch H. Eds; 1979;26:73-126.

19. Harborne JB. Phytochemical methods: a guide to modern techniques of plant analysis. Published by Chapman and Hall, an imprint of Thomson Science, London, UK; 1973.

20. Miller GL. Use of dinitro salicylic acid reagent for determination of reducing sugar. Ann Chem 1959;31:426-8.

21. Phuong TM, Lee D, Lee KH. Regression trees for regulatory element identification. Bioinformatics 2004;20:750-7.

22. Cheng A, Fantus I. Oral antihyperglycemic therapy for type 2 diabetes mellitus. Can Med Assoc J 2005;172:213-6.

23. LoPiparo E, Scheib H, Frei N, Williamson G, Grigorov M, Chou CJ. Flavonoids for controlling starch digestion: structural requirements for inhibiting human $\alpha$-amylase. J Med Chem 2008;51:3555-61.

24. Sabitha V, Panneerselvam K, Ramachandran S. In vitro $\alpha$ glucosidase and $\alpha$-amylase enzyme, inhibitory effects in aqueous extracts of Abelmoschus esculentus (L.) moench. Asian Pac J Trop Biomed 2012;2:162-4.

25. Lobovitz H. $\alpha$-glucosidase inhibitors. Endocrinol Metabol Clin North Am 1997;26:539-51. 
26. Inzucchi SE. Oral antihyperglycemic therapy for type 2 diabetes. Sci Rev 2002;287:360-72.

27. Laar FA, Lucassen PL, Akkermans RP, Lisdonk EH, Rutten GE, Weel C. $\alpha$-glucosidase inhibitors for patients with type 2 diabetes: results from a cochrane systematic review and metaanalysis. Diabetes Care 2005;28:166-75.

28. Thorat K, Patil L, Limaya D, Kadam V. In vitro models for antidiabetic activity assessment. Int J Res Pharm Biomed Sci 2012;3:730-2.

29. Jumepaeng T, Prachakool S, Luthria DL, Chanthai S. Determination of antioxidant capacity and $\alpha$-amylase inhibitory activity of the essential oils from Citronella grass and Lemongrass. Int J Food Res 2013;20:481-5.

30. Bischoff $\mathrm{H}$. Pharmacology of $\alpha$ glucosidase inhibitor. Eur J Clin Invest 1994;24:3-10.

31. Silva MCM, Grossi-de-Sa MF, Chrispeels MJ, Togawa RC, Neshich G. Analysis of structural and physicochemical parameters involved in the specificity of binding between $\alpha$-amylases and their inhibitors. Protein Eng 2000;13:167-77.

32. Ali H, Houghton PJ, Soumyanath A. The $\alpha$-amylase inhibitory activity of some Malaysian plants used to treat diabetes with particular reference to Phyllanthus amarus. J Ethnopharmacol 2006;107:449-55.

33. Davis SN, Granner DK. Insulin, oral hypoglycemic activity agents and the pharmacology of endocrine pancreas. In: Goodman and Gilman's: The pharmacological basis of therapeutics. $11^{\text {th }}$ ed. McGraw-Hill Medical Publication Division: New York. Brunton et al. Eds; 2001. p. 1706-7.

34. Boivin M, Flourie B, Rizza RA, Go VL, DeMagno EP. Gastrointestinal and metabolic effects of amylase inhibition in diabetics. Gastroenterology 1998;94:387-94.

35. Kim JS, Kwon CS, Son KH. Inhibition of alpha glucosidase and amylase by luteolin, a flavonoid. Biosci Biotechnol Biochem 2000;64:2458-61.

36. Lilliooja S, Mott DM, Spraul M, Ferraro R, Foley JE, Ravussin E. Insulin resistance and insulin secretory dysfunction as precursors of non-insulin-dependent diabetes. Prospective Study of Pima Indians. Engl J Med 1993;329:1988-92.

37. Rajeswari P, Krishnakumari S. The potent antihyperglycemic activity of Calocybe indica in streptozotocin-induced diabetic rat's antihyperglycemic activity of Calocybe indica. Int J Pharm Pharm Sci 2013;5:512-5.

38. Brownlee M. Biochemistry and molecular cell biology of diabetic complications. Nature 2001;414:813-20.

39. Evans JL, Goldfine ID, Maddux BA, Grodsky GM. Oxidative stress and stress-activated signalling pathways: a unifying hypothesis of type 2 diabetes. Endocr Rev 2002;23:599-622.

40. Jay D, Hitomi H, Griendling KK. Oxidative stress and diabetic cardiovascular complications. Free Radical Biol Med 2006;40:183-92.

41. Kowluru RA, Kowluru A, Kanwar M. Small molecular weight Gprotein, H-Ras, and retinal endothelial cell apoptosis in diabetes. Mol Cell Biochem 2007;296:69-76.

42. Defronzo RA, Ferranini E. Insulin resistance: a multifaceted syndrome responsible for NIDDM, obesity, hypertension, dyslipidemia and atherosclerotic cardiovascular disease. Diabetes Care 1991;14:173-94.

43. Wi JE, Kim JK, Youn JH. Reduced glucose clearance as the major determinant of postabsorptive hyperglycemia in rats. Am J Physiol Endocrinol Metab 1998;274:257-64.

44. Krishna J, Pandey B, Pathak DB. Characterization of dichotomoceras in the oxfordian of kachchh. J Geol Soc India 2009;74:469-79.

45. Khan MA, Rahman MM, Tania M, Uddin MN, Ahmad S. Pleurotus sajor-caju and Pleurotus florida mushrooms improve some extent of the antioxidant systems in the liver of hypercholesterolemic rats. Open Nutraceuticals J 2011;4:20-4.

46. Prabu M, Kumuthakalavalli R. In vitro and in vivo antidiabetic activity of Calocybe indica $\mathrm{P}$ and C. In: $8^{\text {th }}$ International Conference on Mushroom Biology and Mushroom Products. Organized by Mushroom Society of India; 2014. p. 433-7.

47. Johnny I, Okon J. Antidiabetic effect of Pleurotus ostreatus (Jacq ex Fr) Kumm, mushroom on alloxan induced diabetic rats. Indian J Pharm Biol Res 2013;1:31-6.

\section{How to cite this article}

- $\quad$ Prabu M, Kumuthakalavalli R. Antidiabetic potential of the oyster mushroom Pleurotus florida (mont.) singer. Int J Curr Pharm Res 2017;9(4):51-54. 